\title{
Os Institutos Históricos: do Patronato de D. Pedro II à construção do Tiradentes
}

Cláudia Regina Callari

Doutoranda da USP

RESUMO

Este artigo analisa a trajetória do Instituto Histórico e Geográfico Brasileiro e do Instituto Histórico e Geográfico de Minas Gerais, observando-os no contexto de sua formação e atuação. A produção do saber e a elite política confundiam-se nos dois momentos, sendo que, durante o Império, a leitura da história reiterava a existência da Monarquia. Após 1889, caberia ao IHGMG a recuperação da Inconfidência Mineira sob o aspecto de modelo republicano fundador da História do Brasil. A produção didática reforçou, nos dois casos, a orientação oferecida pelos Institutos Históricos.

Palavras-chaves: Institutos Históricos; livros didáticos; História Nacional.
ABSTRACT

This article analyzes the path of the Historical and Geographical Brazilian Institute and of the Historical and Geographical Institute of Minas Gerais, observing the context of their formation and performance. The production of the knowledge and the political elite mixed up in two moments and, during the Empire, the reading of the history reiterated monarchy existence. After 1889, fell to IHGMG Inconfidencia Mineira, recovery under the first founding republican model of Brazilian History. The didactic production reinforced, in both cases, the orientation offered by the Historical Institutes.

Key words: Historical Institutes; text books; National History 
Vistos com relativo preconceito hoje em dia por determinados setores da comunidade acadêmica, os institutos históricos e geográficos foram pioneiros na coleta e sistematização da documentação histórica, em levantamentos geográficos e em estudos etnográficos e lingüísticos. Foram responsáveis, portanto, pela produção de um saber na própria época em que a separação entre campos diversos do conhecimento estava se delineando e que a história reivindicava para si um estatuto científico, alicerçado em sólida pesquisa documental. Todo esse esforço foi canalizado para a construção da idéia de nação, buscando no passado exemplos e argumentos que apontassem o caminho glorioso destinado ao Brasil. Entretanto, esses "obreiros da história" não possuíam, obviamente, nenhuma formação específica para o historiador nos termos atuais. Eram basicamente membros da elite que ocupavam altos postos na burocracia estatal e políticos de renome. Literatos, advogados, médicos, engenheiros, militares - carreiras de praxe a serem seguidas pelos filhos da elite - eram as principais ocupações daqueles que se dedicavam com afinco aos projetos de seus institutos.

Durante muitos anos o Instituto Histórico e Geográfico Brasileiro (IHGB) brilhou solitário como único expoente da produção do saber histórico. Instituição localizada no Rio de Janeiro, sede da corte e portanto credenciada a representar toda a nação, reuniu em seus quadros a nata da sociedade e da intelectua60 lidade da época, aglutinando membros locais - sócios efetivos - e de outras partes do País e do mundo - sócios correspondentes. Sua hegemonia só seria parcialmente quebrada em 1862, com a criação do Instituto Arqueológico e Geográfico Pernambucano (IAGP), este com acentuada preocupação regional. Posteriormente, novos institutos com base local começaram a pipocar, como o de São Paulo, fundado em 1894, e o Mineiro, em 1907, para citar apenas os da região Sudeste. Todos os institutos locais procuravam se filiar, por um lado, ao modelo proposto pelo IHGB - o que pode ser verificado pela comparação dos estatutos, formato das revistas e intercâmbio entre seus membros -; por outro, buscavam justamente realçar aspectos da história local, salientando a importância da região na composição da história nacional.

O IHGB constituiu-se em instituição pioneira e sólida que, contando com forte subvenção oficial e intervenção pessoal do próprio imperador nos seus 50 primeiros anos, nunca deixou de publicar sua revista. Enquanto instituição mais duradoura e nacional, teve atuação decisiva nos debates historiográficos e na sua divulgação, ainda que de maneira indireta, através dos livros didáticos. O Instituto Histórico e Geográfico de Minas Gerais (IHGMG), por sua vez, procurou justificar os interesses políticos e econômicos mineiros através do passado - ocupando aí papel central o estudo da Inconfidência Mineira -, que asseguraria o local de destaque ocupado por Minas Gerais dentro da Federação. Acrescenta- 
mos ainda o Arquivo Público Mineiro que, embora com funções diferentes, foi uma instituição irmã do Instituto mineiro: não só muitos de seus membros eram comuns como também sua revista foi utilizada para publicações do IHGMG, enquanto este não possuía ainda revista própria.

\section{O CONTEXTO DO IMPÉRIO E A CRIAÇÃO DO IHGB}

Em 18 de agosto de 1838, reunido o Conselho Administrativo da Sociedade Auxiliadora da Indústria Nacional, foi apresentada a proposta para a criação do Instituto Histórico e Geográfico Brasileiro, assinada pelo marechal Raimundo José da Cunha Matos e pelo cônego Januário da Cunha Barbosa. Em 21 de outubro, os 27 fundadores do IHGB reuniam-se pela primeira vez em uma sala do Museu Nacional. Dos 27 membros iniciais, 12 eram conselheiros de Estado - deste grupo, 7 eram também senadores -, 1 era exclusivamente senador, 3 eram professores ( 2 do recém-fundado Colégio Pedro II e 1 da Academia Militar); havia ainda outros membros ligados à burocracia estatal: desembargadores, funcionários públicos, militares, um pregador imperial (caso de Januário da Cunha Barbosa). Aparecem apenas 2 advogados (sem qualquer outro indicador de cargo público), 1 comerciante e 1 engenheiro. A maioria dos fundadores do IHGB, além de desempenhar funções dentro do aparelho de Estado, tinha como elemento nivelador o fato de integrar uma geração ainda nascida em Portugal e transferida compulsoriamente ao Brasil por ocasião das transformações geradas pelo período napoleônico. Socializado pela educação fornecida por Coimbra refratária, portanto, aos ideais da Revolução Francesa - tal grupo seria dominante até o início dos anos 50 - tanto no IHGB como na burocracia estatal -, quando seria substituído pela geração formada no Brasil.

De maneira geral, pode-se afirmar que o perfil dos membros que engrossaram as fileiras do IHGB foi este: elementos oriundos da burocracia estatal, logo comprometidos com a ordem que representavam, apesar do Instituto se definir como instituição político-cultural - apartada, desse modo, dos debates políticos. A hegemonia estabelecida pelos membros do IHGB - que representavam também a elite pensante - era dupla, estendendo-se pelo Estado e pela sociedade civil, na qual possuíam ativa participação como clérigos, jornalistas e professores. Destacava-se aí o papel da escola, canal de formação dos filhos da elite - por conseguinte, de reforço do cimento ideológico - e, conseqüentemente, de difusão dos valores dominantes pela sociedade.

Criado nos últimos anos de um dos mais conturbados períodos da história brasileira, o IHGB carregaria marcas indeléveis dessa época. Após a abdicação

de D. Pedro I, o cenário político encontrava-se fracionado, grosso modo, em três forças: os moderados, defensores da Monarquia liberal; os exaltados, partidários 
do federalismo e, em boa parte, da República, e os restauradores, que tramavam a volta do imperador. Porém, após a experiência de uma Monarquia com tendências fortemente absolutistas, tornava-se premente a proposição de reformas de cunho descentralizador. Tais reformas, como se sabe, culminariam no Ato Adicional de 1834, cujo redator foi o mineiro Bernardo Pereira de Vasconcelos, deputado e futuro ministro do império e senador. Na legislatura de 1826, ao estrear na vida política, propôs na Câmara que se adotassem no Brasil instituições judiciárias segundo o modelo britânico, mencionando em discurso, de maneira ainda bastante positiva, a Inconfidência Mineira, assegurando para Minas Gerais um papel de promotor da Independência:

É fama que os mineiros já pelo ano de 1790 conceberam o majestoso projeto de sacudir o jugo europeu: os homens mais gentis nas letras e nas armas eram apontados como os autores desta gloriosa empresa que não chegou a realizar-se.(...) Um deste varões ilustres perdeu a vida no patíbulo; outro, que eu chamarei o Catão das Minas, o sábio e intrépido Cláudio Manuel da Costa, foi assassinado na masmorra pelo visconde, que assim roubou a glória a seus desembargadores lisboenses, e os Gonzagas, Alvarengas e outros que tais foram condenados a acabar suas preciosas vidas nos mais insalubres rochedos da costa africana. ${ }^{1}$

Entretanto, no período regencial, uma vez afastado o perigo efetivo da restauração portuguesa, a situação foi bem outra. Ante o medo da anarquia e a possibilidade real de fragmentação da nação, muitos dos principais líderes políticos - capitaneados por Bernardo Pereira de Vasconcelos - recuaram em relação às reformas propostas. Tentando explicar sua mudança de posição, foi assim que este político se expressou:

Fui liberal; então a liberdade era nova no país, estava nas aspirações de todos, mas não nas leis, não nas idéias práticas; o poder era tudo; fui liberal. Hoje, porém, é diverso o aspecto da sociedade: os princípios democráticos tudo ganharam e muito comprometeram, a sociedade que então corria risco pelo poder, corre agora risco pela desorganização e anarquia. (...) Os perigos da sociedade variam: o vento das tempestades nem sempre é o mesmo: como há de o político, cego e imutável, servir o seu país? ${ }^{2}$

A Inconfidência começa a ser vista nesse período, pelos arvoradores do regresso, como movimento que representaria, simbolicamente, efetiva ameaça à unidade nacional, não só pelo caráter local como também pelo teor republicano. O movimento mergulha então num longo silêncio, do qual só emergirá efetivamente com a obra de Joaquim Norberto, lida nas sessões do Instituto a partir de 1860 e só publicada em 1873. Após a tumultuada experiência regencial, volta-se 
ao trono como a fonte única de ordem e possibilidade de coesão nacional. Isso explicaria a leitura que foi feita da Inconfidência Mineira durante boa parte do Segundo Reinado e os esforços realizados pelos historiadores - empenhados na construção da historiografia nacional - em compreender a Inconfidência como movimento fadado ao fracasso, posto que republicano. $\mathrm{O}$ trono permaneceria como o único referencial para toda uma geração de historiadores.

É dentro dessa perspectiva que se pode compreender a íntima relação que se estabelece entre o Instituto e a Monarquia, cristalizada na figura de D. Pedro II - o imperador “amigo das letras". Já na primeira sessão, o Instituto concede ao jovem imperador o título de protetor da agremiação, tornando clara sua perfeita simbiose com o Estado. As sessões públicas comemorativas do aniversário da instituição, a partir de 1849, foram deslocadas para o dia 15 de dezembro, data em que o imperador passou a freqüentar as sessões ordinárias. Essas sessões eram bastante longas, e seguiam um roteiro pre-estabelecido: inicialmente o presidente - figura que representava a instituição, geralmente um político de prestígio - fazia uma apresentação laudatória, evocando o caráter generoso e sábio do soberano, bem como as virtudes da Monarquia; em seguida o primeiro-secretário - que se incumbia do trabalho mais pesado, redigindo atas e preparando reuniões - apresentava um resumo das atividades do ano e, por último, o orador entoava o elogio aos sócios falecidos. Em 1840, a sessão não pôde ser completada: o jovem imperador e suas irmãs, sentindo-se incomodados, retiraram-se após provavelmente horas intermináveis de discurso.

O Instituto, que se espelhava nas agremiações iluministas, entretanto adotava o modelo da vida de corte girando em torno do soberano: em 1846, não celebrou a sessão pública de aniversário, já que o imperador encontrava-se fora do Rio de Janeiro. Como no Antigo Regime, em que a etiqueta sobrevivia mal à ausência do monarca, o IHGB estabeleceu uma íntima relação com a Monarquia: sem o soberano não havia espetáculo. Na sessão magna de 1865, o presidente do Instituto, Cândido José de Araújo Viana, então visconde de Sapucaí, comemorou o retorno do imperador ao Rio de Janeiro, às voltas com o conflito com o Paraguai:

É verdade que o Instituto celebrou suas sessões ordinárias em períodos regulares; os sócios, cujos nomes estão registrados nas atas, compareciam assíduos; mas quem não vê que tais sessões, frias e desmaiadas, deviam ressentir-se da ausência do sol que as aquecia e lhes dava cor? Esse brilhante sol iluminava então as terras do sul do Império e com seus fulgurantes raios espantava trevas e dissipava espessos nevoeiros. $^{3}$

Em 1887, ausente Sua Majestade em viagem pela Europa, Sacramento Bla- 
ke propôs que fosse inserido na ata um voto "de simples saudade, porque esta palavra exprime um sentimento duplo, a mágoa motivada pela ausência do objeto que se ama e nos merece toda a estima e respeito, e o desejo ardentíssimo de se tornar a possuir esse mesmo objeto".

Um costume de praxe no Instituto era o de enviar delegações para cumprimentar o monarca por ocasião de inúmeras datas. Além das efemérides de cunho pessoal (aniversário, casamento, natalício de príncipes), havia aquelas que deveriam ficar gravadas na história da nação: o 7 de setembro, o juramento da primeira Constituição (25 de março), a Abdicação (31 de abril). As alocuções dirigidas ao imperador eram momento de fixação dos elementos particulares da nossa história, reafirmados sempre em contraposição ao outro:

Senhor! Prodígios de alta ventura nos sobem à mente sempre que renasce este dia, todo da pátria: à voz de um príncipe magnânimo surdiu o trono constitucional do Brasil; a Europa, admirada, contemplou nesse sucesso um dos passos mais gigantescos da civilização, o magnífico triunfo das novas idéias, políticos profundos nos auguraram uma carreira de prosperidades, e acompanharam com seus votos a emancipação de um povo, que teve a sabedoria de respeitar seus antigos hábitos, suas herdadas tendências morais; e o sol, que nas alturas do Ipiranga luzia na heróica cena de 7 de Setembro de 1822, passados apenas quatro anos, visitando o mesmo signo, testemunhou já o ato de reconhecimento da nossa Independência, viu irmãos reconciliados entrarem em paz na posse da partilha que havia a cada um assinalado a natureza, sem as torrentes de sangue que à outra nação têm custado a conquista da própria liberdade. ${ }^{5}$

Na mesma data, no ano seguinte, o barão de Monte Alegre, chefe da deputação que foi cumprimentar o imperador, proclamou:

Sacrificando uma coroa, ele firmou a realeza em nossa terra, e à sombra da realeza o Brasil tem podido conservar-se inteiro e desenvolver os germens de prosperidade, com que a providência o enriqueceu, sem passar pelas convulsões que sofrem ain$\mathrm{da}$, sem poderem antever o termo delas, os povos que nos rodeiam. ${ }^{6}$

A manutenção da ordem - projeto maior do regresso, ao qual aderiram também os liberais - só poderia ser efetivada mediante a preservação da integridade territorial. Tal integridade só seria conseguida por meio de um esforço efetivo de se criar um passado comum para a nação una que despontava - tarefa desempenhada pelos intelectuais do Instituto Histórico e Geográfico Brasileiro. A Inconfidência Mineira nesse processo é bastante elástica: se por um lado é desacreditada por seu conteúdo republicano, em contraposição à estabilidade proporcionada pela Monarquia, por outro vai paulatinamente se convertendo em movimento nacional, representante das mais profundas aspirações dos brasileiros. 
Da mesma maneira que a revista veicula um discurso monárquico, de suas páginas também podemos acompanhar a decadência do Império. Assim, a revista nos fornece um painel das transformações da sociedade brasileira no final do século XIX, sendo possível apreender-se a emergência da idéia republicana nas filigranas do discurso oficial. À medida que a idéia avança, a reação monárquica torna-se explícita. É assim que os últimos dias do Império são pressentidos pelo senador Alfredo Taunay na defesa apaixonada de uma forma de governo que já se sabia condenada:

Para que romper com um passado honroso e nobre, que é a segurança do porvir próspero e glorioso? (...) Conseguidos os almejados fins poderá a Monarquia confiantemente perguntar à República: "Que mais quereis? Que horizontes novos mostrais ao patriotismo e ao desinteresse? Apontai-m'os e em busca deles logo partirei!

E termina com uma profecia:

Ainda aí os republicanos do futuro hão de sentir a obsessão da Monarquia, como que ponta de remordimento a pungir-lhe o seio por a terem tanto combatido e tamanhas injustiças lhe irrogado. Nessa mulher fascinadora que exaltaram verão, como que em graciosa aparição, a fisionomia meiga e bondosa daquela que redimiu os desgraçados escravos, e ao seu lado se alteará, sombra augusta e gigante, o vulto solene e calmo de D. Pedro II, o grande Patriota!

Derrubada a Monarquia, o IHGB não aceitaria o novo governo de imediato. Amparados pelo estatuto científico da Instituição - isolados, portanto, dos movimentos políticos do país -, seus membros recusam a proposta do barão Homem de Mello para se nomear uma comissão a fim de saudar o governo provisório. Essa situação não iria durar muito: era necessário que o Instituto se alinhasse aos novos tempos - inclusive porque dependia de subvenção oficial. Em 1891, Deodoro da Fonseca - irmão do $1^{\circ}$ secretário João Severiano da Fonseca - torna-se presidente honorário do Instituto, praxe seguida em relação aos próximos governantes. Entretanto, o Instituto não perde a oportunidade de enaltecer a figura de D. Pedro, que se confundia com a própria Monarquia. Ao emitir o parecer sobre o livro de Frank Vincent, viajante norte-americano, diz o Instituto:

Excelente, excelente livro no geral. E ainda mais, predispõe a seu favor a pequena dedicatória a D. Pedro II, feita quando ele era Imperador - e publicada quando o imortal brasileiro não era mais o monarca americano dispensador de graças e favores, mas simplesmente o desterrado filósofo scholar and scientist, como diz o Sr. Vincent (...). ${ }^{8}$

Nos anos seguintes, o IHGB continuaria enviando as congratulações habi- 
tuais ao monarca exilado. Após sua morte, o Instituto decretou luto por sete dias e cobriu de crepe durante um ano a cadeira que o imperador usava para presidir as sessões. Quando Prudente de Moraes presidiu a sessão magna em 1894, preferiu sentar-se ao lado dos membros do Instituto, após ser informado que a cabeceira da mesa era ocupada por Pedro II ${ }^{9}$. Podemos interpretar a atitude como a exteriorização do respeito que se dedicava à Monarquia, mas também como o desejo do novo regime fundar-se sobre uma aparente igualdade.

Monarquia e República são confrontadas em vários momentos. Se não se faz mais abertamente a opção pela primeira forma de governo - ainda que o IHGB fosse um reduto dos seguidores do antigo regime -, ao menos reafirma-se a importância da Monarquia na preservação da integridade territorial e a falta de maturidade dos brasileiros para a República:

Por nossa educação política não estávamos preparados para essa forma governativa; nós colonos de uma nação submetida a um governo absoluto, ignorante, do país mais atrasado da Europa, poder-nos-íamos comparar com a florescente colônia inglesa, habituada ao self government? ${ }^{10}$

Com a consolidação da República, muitos republicanos históricos passam a incorporar o espírito da agremiação: uma vez que a Monarquia não representava mais nenhum perigo, tratou-se de amalgamar a história num grande continuum, reverenciando a figura do imperador deposto e o papel histórico desempenhado pela Monarquia. A profecia de Taunay cumpriu-se.

\section{OS MEMBROS DO IHGB E A EDUCAÇÃO}

Na primeira publicação do Instituto aparecem seus objetivos expressos pelos estatutos: "coligir, metodizar, publicar ou arquivar os documentos para a história e geografia do império no Brasil; e assim também promover os conhecimentos destes dois ramos filológicos por meio do ensino público, logo que o seu cofre proporcione esta despesa", reza o artigo $1^{\circ}$. Além da fixação do número de 50 sócios, haveria quantidade ilimitada de sócios correspondentes e honorários, "cujo título será conferido às pessoas que por sua avançada idade, consumado saber e distinta representação estejam no caso de dar crédito ao Instituto". Percebe-se aí que os critérios de seleção para a agremiação passavam pelo círculo de relações pessoais - ainda não se exigia nenhum trabalho próprio aos aspirantes: as portas do Instituto seriam abertas mediante a mera indicação de um de seus membros. Por fim, buscava o Instituto estabelecer correspondência com sociedades de igual natureza, bem como ramificar-se nas províncias do Império.

Aos intelectuais do IHGB competia, portanto, a definição do projeto da na- 
ção de que se falava. Esse projeto nacional incluía, além da defesa da Monarquia, a apologia da centralização (o que se refletia na própria concepção do IHGB como núcleo produtor de saber) e do catolicismo, alicerce da nacionalidade. $\mathrm{O}$ caminho para a tão almejada civilização, pensada segundo os moldes europeus, deveria passar, inevitavelmente, pela educação, elemento fundamental na unificação ideológica das elites. A formação dos filhos das famílias abonadas seguia um trajeto quase que obrigatório: às primeiras letras, geralmente aprendidas junto a um professor particular, seguiam-se alguns anos - ou todo o curso secundário - no Colégio Pedro II; posteriormente, via de regra optava-se pela formação jurídica em São Paulo ou no Recife.

Apesar de a Constituição de 1824 assegurar a educação primária a todos os cidadãos, muito pouco foi feito durante o Império. Uma vez que a educação era voltada para a formação das elites, só o ensino secundário e o superior foram alvo de atenção. Vigoravam então dois sistemas paralelos de ensino, possibilitados pelo Ato Adicional de 34: enquanto o ensino primário era de competência exclusiva das províncias, o secundário e o superior - obviamente tidos como mais importantes - eram controlados pelo governo central. Além disso, uma vez que praticamente inexistiam estudos seriados, a admissão ao ensino superior só se daria - exceto para os bacharéis do Colégio Pedro II - a partir da realização dos exames gerais, também coordenados pelo governo central. Em resumo, a educação caracterizava-se por uma imensa fragmentação, pois à elite interessava apenas o diploma superior - sobretudo o obtido junto aos cursos jurídicos -, porta de entrada para a vida política. Não era necessário, portanto, o estudo metódico e seriado: tanto pais como alunos estavam interessados em resultados imediatos, matriculando seus filhos nos cursos preparatórios e realizando os exames isoladamente, por disciplinas.

O decreto de 2 de dezembro de 1837, graças aos esforços do então ministro Bernardo Pereira de Vasconcelos - também membro do IHGB e idealizador da política do Regresso, que levaria à Lei de Interpretação do Ato Adicional transformou o Seminário de São Joaquim, antigo Seminário dos Órfãos de São Pedro, no Colégio Pedro II. O objetivo, segundo seu criador, não era competir com os estabelecimentos particulares, mas sim dotar a corte de uma instituição modelar, calcada em moldes franceses. Para se ter uma idéia, na reforma de 1856 foram adotados os programas dos liceus nacionais franceses. A ênfase recaía sobre os estudos clássicos, notadamente latim e literatura. Os estudos eram seriados, inicialmente com oito anos de estudo e depois reduzidos para sete. Ao aluno que concluísse o curso era atribuído o grau de bacharel em letras, título com o qual poderia ingressar livremente em qualquer instituição de ensino superior. Na prática, porém, muitos alunos não concluíam o curso, preferindo submeter- 
se aos exames gerais antes dos sete anos previstos pelo curso regular. $\mathrm{Na}$ verdade, pouquíssimos alunos chegavam a concluir o secundário no Pedro II: computando-se o número de alunos que se graduaram anualmente de 1843 a 1901, temos a baixíssima média de 11,9 alunos que se formavam por turma.

Muitos dos membros do IHGB foram também professores, principalmente do Pedro II: afinal, ser professor de uma instituição tão sólida e renomada era sinônimo de competência intelectual, não apenas nos anos imediatamente posteriores à sua fundação, mas durante todo o período estudado. Muitas vezes, o trabalho junto ao magistério serviu como ponte para a confecção de obras didáticas, que engrossavam substancialmente as rendas minguadas do autor. De fato, muitos dos professores de história do colégio eram nomes de projeção no país em vários meios: Justiniano José da Rocha, Gonçalves Dias, Francisco Inácio Marcondes Homem de Mello, futuramente barão, Joaquim Manoel de Macedo, José Maria da Silva Paranhos - o barão do Rio Branco -, Escragnolle Doria, Capistrano de Abreu, Matoso Maia e João Ribeiro.

Ao caracterizar a política saquarema, Ilmar Rohloff de Mattos fez sobressair o lugar de destaque atribuído à educação:

Educar tornava-se, pois, ação por meio da qual cada um dos alunos deveria adquirir os princípios éticos e morais considerados fundamentais à convivência social, aderindo de modo consciente ao espírito de associação. Era assim o complemento do ato de instruir, que propiciava a cada indivíduo os germes da virtude e a idéia dos seus deveres como homem e cidadão. Instruir e educar eram, em suma, uma das maneiras - quiçá a fundamental - de fixar os caracteres que permitiriam reconhecer os membros que compunham a sociedade civil, assim como aqueles que lhe eram estranhos, para além da fria letra do contexto constitucional. ${ }^{11}$

Uma vez que o conceito de civilização ancorava-se no velho mundo, nada mais lógico do que recorrer a ele para se civilizar e instruir. Em muitas províncias foram enviados professores à Europa para aprender mais sobre os métodos de ensino. Também era aspiração antiga dos políticos que se preocupavam com a educação o estabelecimento de uma corporação nos moldes da universidade francesa, criada por Napoleão Bonaparte, que congregava e fiscalizava toda a educação. Desde 1843 o deputado Justiniano José da Rocha propunha uma maior inspeção governamental, tamanha era a facilidade de se abrir escolas, tanto que chegou a redigir um projeto procurando impor limitações que dificultassem a abertura de estabelecimentos de ensino. Pouca atenção foi dada ao projeto, e depois de muitas reformulações e tentativas ele foi aprovado em 1851, só sendo efetivado em 1854.

Alguns anos antes já se notava a preocupação com a política educacional, 
principalmente através da atuação do Cônego Januário da Cunha Barbosa. Fundador do IHGB, teve decisiva participação na política educacional, trazendo esses debates ao Instituto, principalmente nos anos iniciais. Levou seu nome o projeto aventado na legislatura de 1826 que, dentre outros, propunha um ensino escalonado, direcionado a classes sociais distintas. Propunha também a criação do Instituto do Brasil, uma corporação que dirigiria a instrução pública, escolhendo e aprovando os compêndios utilizados. Percebe-se a influência do modelo francês, não só no atrelamento da educação às classes sociais como também nos desígnios de criar uma entidade que pudesse coordenar as atividades educacionais.

O que caracterizou verdadeiramente o ensino durante todo o período imperial foi sua péssima qualidade. Nos relatórios enviados às assembléias provinciais eram freqüentes as queixas em relação à instrução. Apesar de a educação beneficiar apenas parcela restrita da população, nem entre os afortunados a situação era mais animadora. Além do grande problema mencionado - o caráter fragmentário do ensino -, faltavam professores capacitados, remuneração e inspeção suficientes, instalações adequadas e compêndios - em quantidade e qualidade.

Ao contrário do que muitos esperavam, a República não veio alterar essa situação. Não obstante o federalismo vigente, o governo republicano conservou a centralização da educação, mantendo o ensino secundário e superior sob sua influência. A despeito das tentativas de se romper com o estado fragmentário do ensino, as inúmeras reformas que se sucederam não conseguiram alterar o panorama, e o secundário continuou a ser exclusivamente uma etapa necessária para o ensino superior, embora os compêndios tenham se multiplicado. Em 1890 a Reforma Benjamin Constant, que transformava o Colégio Pedro II em Ginásio Nacional, previa também a extinção dos parcelados, o que não se efetivou. No novo regime sucederam-se inúmeras reformas de ensino, experimentando diversas medidas que não se revelaram viáveis ou não entraram em prática. A situação só começou a se alterar com a reforma de Francisco Campos em 1931, que adotou programas únicos para todas as escolas, cuja elaboração estaria a cargo do Ministério da Educação.

No entanto, se no Império a educação se fazia necessária enquanto alicerce da nacionalidade, na República era a condição imprescindível para o exercício da cidadania. Mais do que um direito, o voto constituía-se numa "função pública que não pode ser exercida senão pelos que são capazes de compreender sua importância"' ${ }^{2}$. Nesse quadro podem ser inseridos os debates sobre a criação da "Universidade Popular Livre" a partir de 1901, destinada à complementação dos 
estudos básicos, e as discussões encetadas pelos movimentos nacionalistas dos anos vinte.

Particularmente até meados do Segundo Reinado os livros didáticos eram problema constante, chegando a comprometer o andamento dos cursos. Eram utilizados manuais repetitivos, que não traziam nenhuma renovação.

No caso de História do Brasil somava-se um outro problema: a criação de compêndios, uma vez que a tradução, possível em outras disciplinas, era aqui insuficiente. O IHGB, como centro produtor de saber, envolveu-se na questão. Já em 1840 foi travada uma longa discussão sobre livros didáticos. Justiniano José da Rocha - futuro autor de livros didáticos de História Geral - , tendo sido nomeado professor de História Pátria no Colégio Pedro II, reconheceu que existiam poucos compêndios disponíveis sobre o assunto, instando ao Instituto para nomear uma comissão especial a fim de organizar um compêndio de História do Brasil. Contra a proposta levantou-se Januário da Cunha Barbosa, uma vez que alguns pontos da história não estavam suficientemente claros e além disso, indicando o compêndio do sócio Pedro de Alcântara Bellegarde. A questão ficou pendente, não voltando a ser discutida. Havia, portanto, a interferência , ainda que indireta, do IHGB não só na produção do saber didático como na legitimação desse saber. Ser membro do Instituto era sinal automático de competência do autor. Foi nesse sentido que se pronunciou o diretor do Conselho de Instrução Pública, Eusébio de Queirós, pedindo ao Instituto que escolhesse um compêndio de História do Brasil a ser seguido nas escolas. O mesmo diretor enviou um exemplar de uma obra para ser examinada pelo Instituto. No mesmo ano, na sessão magna, Joaquim Manuel de Macedo, então $1^{\circ}$ secretário - também professor do Colégio Pedro II -, reclamou da ausência de compêndios escolares, pois os estrangeiros revelavam-se pouco satisfatórios. Poucos anos depois Macedo publicaria seu primeiro compêndio de História do Brasil. Através de suas sucessivas edições, é possível perceber como veio a preencher um espaço até então vazio.

Para minimizar essa situação de carência absoluta, a solução encontrada pelos governos provinciais foi, muitas vezes, a contratação de professores capacitados para a produção do material. Em 1880 o relatório do presidente da Província do Rio de Janeiro, Marcondes de Andrade, anunciou ao seu sucessor:

O dr. Joaquim Manoel de Macedo, que por contrato se obrigara a escrever um livro de história pátria e outro de corografia da província para as escolas primárias, entregou os manuscritos os quais foram examinados pelo dr. Joaquim Mendes Malheiro (professor de história e geografia da Escola normal) e depois deste exame e da declaração do diretor da instrução de estar cumprindo o contrato, mandei pagar o resto da remuneração estipulada. ${ }^{13}$ 
A situação era tão caótica que em 1872 o regulamento da instrução pública de Minas Gerais estipulou prêmios aos professores ou quaisquer outras pessoas que compusessem compêndios para uso das escolas, desde que os livros fossem aprovados pelos órgãos competentes.

De fato, havia mais material disponível sobre os outros países do que sobre o Brasil. Se era propósito do Instituto colaborar na criação da História Nacional, arquivando documentos, reescrevendo a história pátria, fornecendo exemplos edificantes à mocidade, dever-se-ia então agir através da educação. É também com esse objetivo que a partir da década de 60 muitos de seus membros - que já eram professores - tornaram-se autores didáticos, chamados para engrossar um filão novo do mercado, mas que se anunciava absolutamente promissor: o mercado editorial. A transposição didática dos saberes produzidos e armazenados pelo Instituto também se constituía em uma fonte a mais de rendimentos para muitos, além de uma maneira de divulgar para um público mais amplo o conhecimento sistematizado pela agremiação.

\section{A VISÃO DA HISTÓRIA DENTRO DO IHGB}

Denominado acertadamente de "século da história", os anos 1800 caracterizaram-se pela preocupação sistemática e permanente com a pesquisa histórica. Ainda sob o impacto da Revolução Francesa, o século se iniciou sob os auspícios do romantismo e do nacionalismo, que iriam transformar o Estado em gerenciador da pesquisa histórica. Esse processo foi particularmente forte na França com Guizot, mas também na Alemanha, Bélgica, Itália e Portugal, com os trabalhos de Alexandre Herculano, modelo e referência no IHGB. O século XIX assistiu ainda ao amadurecimento da historiografia erudita e da crítica documental (consolidada com Leopold Von Ranke) e do positivismo comteano, após a década de 70. No Brasil foi Varnhagen o iniciador da crítica histórica, a partir da busca nunca antes empreendida de documentos, sobretudo em arquivos da Europa, para produzir a sua História Geral do Brasil. Enquanto única obra globalizante sobre o tema produzida por um brasileiro no século XIX, exerceu profunda influência na historiografia e nos manuais didáticos. No início do século destacou-se Capistrano de Abreu, sócio do IHGB desde 1887: embora pouco tenha participado das discussões no Instituto, seu nome era referência e motivo de orgulho para a instituição.

É clara, portanto, a vinculação entre a constituição dos Institutos e um movimento maior que se desenvolvia na Europa, que conciliava, no mesmo espaço, um discurso historiográfico emergente e o nacionalismo. É só dentro desta perspectiva que se pode compreender a atuação dos membros do IHGB e sua visão 
de história. Toda essa produção era marcada pelo "lugar social" do discurso: não se podia esquecer quem falava e de onde falava.

Empenhado no desenvolvimento da historiografia nacional, o IHGB preocupou-se, desde o início, com o estabelecimento de uma marca particular para nossa história, sem se desvincular, simultaneamente, das grandes matrizes teóricas européias. Já na primeira sessão, em $1^{\circ}$ de dezembro de 1838 , foi lançada a questão que serviria de base para futuras discussões, mostrando o empenho do Instituto em assentar as bases da História Nacional: "Determinar-se as verdadeiras épocas da história do Brasil, e se esta se deve dividir em antiga e moderna, ou quais devem ser suas divisões." ${ }^{14}$ De fato, as primeiras sessões foram permeadas por discussões sobre os elementos nacionais; limites territoriais do Império, periodização, discussão e emissão de parecer sobre as obras de História do Brasil escritas por estrangeiros, como as de Jonh Armitage e Ferdinand Dénis. Toda essa discussão culminaria no concurso sobre a melhor maneira de se escrever a História do Brasil, cujo vencedor seria o naturalista alemão Von Martius (17941868), que esteve no Brasil com Spix por ocasião do casamento de D. Pedro I com D. Leopoldina. Em sua monografia, Martius desenvolveu a idéia de que a singularidade do Brasil jazia no cruzamento racial, reafirmando entretanto a hierarquia natural entre as raças. Combinava, assim, as teorias em voga na civilizada Europa, sem deixar de apontar para as particularidades nacionais. Além de Martius, foi apresentado o artigo de Julio de Wallestein, que propôs que a história política fosse escrita através do sistema de décadas, à maneira de Tito Lívio; as partes civil, eclesiástica e literária deveriam vir como um apêndice ao final do texto. O parecer do Instituto, inteiramente favorável ao texto de Martius, revelava como este se inseria no seu propósito de construir uma história da nação que tentava criar uma identidade própria.

O exame das conferências proferidas e dos artigos publicados na Revista do IHGB revela uma acentuada preferência pelos temas políticos - que vai decrescendo ao longo do século XX - e pelos períodos passados, uma vez que a proximidade com o objeto de estudo poderia comprometer a tão proclamada neutralidade do historiador. Pode-se observar ainda que há uma nítida incidência dos grandes temas políticos, notadamente o Descobrimento - momento que assinala a integração do Brasil ao time das nações conhecidas e civilizadas - e a Independência, que marca o nascimento do Brasil como nação autônoma. Posteriormente, a República seria incorporada a essa escala evolutiva. Esses seriam os grandes temas, marcos periodizadores da História do Brasil, para onde confluíam os “pequenos" temas. É nessa perspectiva, também, que a Inconfidência Mineira seria entendida: após se converter em objeto de estudo - antes relegada ao limbo da historiografia - foi vista como movimento precursor da Independência e, 
mais tarde, também da República. Em ambos os casos, a explicação para o seu fracasso era a mesma: o "País" ainda não estava pronto. A história constituiu-se, assim, numa linha contínua, em que as "rupturas" só reafirmaram os períodos anteriores:

As etapas do progresso humano são nitidamente marcadas na história da civilização. A cada época, na evolução dos povos, corresponde um ideal. O nosso, em 1822, foi o da independência. A unidade nacional caracterizou em seguida, o período da Regência. Depois, no $2^{\circ}$ Reinado, ele se concretizou na consolidação e pacificação do Império, até 1870, quando o problema da emancipação dos escravos começou a preocupar seriamente os espíritos. E, nos anos que se seguem ao Ministério Rio Branco, onde culminou a Monarquia, é o ideal democrático que nos conduz à abolição e à República. Estava cumprida a missão histórica do império, cujo trono, durante quase meio século, D. Pedro II tanto dignificou pelas suas altas virtudes morais e cívicas e pelo seu acrisolado amor ao país. ${ }^{15}$

Trata-se de um momento singular na historiografia brasileira: a transição de um período em que a tradição e a memória coletiva confundem-se com a história - a chamada concepção clássica - para o período da concepção moderna, alicerçada na cientificidade e na base documental. É interessante observar que o recuo da concepção clássica não significa sua eliminação, pois alguns de seus elementos convivem harmoniosamente com o estabelecimento de um novo critério de veracidade histórica. Refiro-me aqui especificamente ao significado pedagógico da história - historia magistra vitae, que remonta a Cícero - como um amplo repertório das experiências humanas, dominante no IHGB. Tal concepção se coaduna perfeitamente com o propósito de estabelecer os limites do Estado Nacional, buscando exemplos no passado que legitimassem o presente e formassem os herdeiros desse Estado. Por muito tempo, a história continuará sendo a mestra da vida no Instituto, sobretudo junto aos membros mais velhos:

A história é a grande e judiciosa mestra da vida que, com rectidão e firmeza, encaminha e, pela expressão da verdade, assegura o destino das nações; é a luz que esclarece a mente dos que as dirigem, evitando os erros e os perigos que os rodeiam; a lição sábia e profunda que, pela doutrina e pelo exemplo, educa os povos, para que, na consciência dos seus direitos e deveres, saibam bem sustentá-los e cumpri-los. ${ }^{16}$

No entanto, a proposição, adaptando-se aos novos dias, passou a incorporar o instrumental das ciências sociais. Voz discordante nesse sentido foi a de Pedro Augusto Carneiro Lessa, que não viu na história uma finalidade pedagógica: alguns historiadores desse período (clássico) alimentavam a pretensão de fazer da história um vasto repositório de lições políticas e morais, a "mestra da vida", 
para afirmar em seguida que tal concepção era ainda presente em Alexandre Herculano e Oliveira Martins. Pedro Lessa nutriu-se das idéias do famoso historiador inglês Buckle, que pregava um modelo de conhecimento determinista e científico.

Ao longo de sua história, o IHGB tratou de combater as correntes de pensamento que lhe eram contrárias, reivindicando para o historiador estatuto específico, devendo ser subsidiado pelo governo "para não distrair o seu espírito com as necessidades da vida material”. Ao historiador estava assegurada uma posição de destaque como construtor da nação. Continuou o primeiro secretário, Manoel de Araújo Porto-Alegre: No verdor da civilização temos ainda elementos que é preciso combater energicamente, porque a filosofia do materialismo quer invadir todas as classes sociais e assenhorear-se da situação.

O historiador quando preenche devidamente a sua missão é um benemérito da pátria e da humanidade: poderosa dualidade na demolição e reconstrução do passado, prepara os espíritos para o futuro na indicação moral dos resultados da experiência humana. ${ }^{17}$

Mais tarde, criticou-se abertamente o positivismo, chegando o Instituto a cogitar da possibilidade de difundir algumas obras que pudessem fazer frente a essa corrente, traduzindo-as e vendendo-as a preço mais acessível. O positivismo abalava as bases sobre as quais se assentava o Instituto: a religião e a Monarquia. Por isso, mesmo após o advento da República, manteve-se ainda refratário a essa corrente. Foi o caso de Rozendo Muniz Barreto, professor de história e corografia pátrias no antigo Colégio Pedro II, então denominado Ginásio Nacional, que abandonou o cargo a partir da instalação do Novo Regime devido à imposição da doutrina positivista na cadeira de filosofia.

Aos membros do Instituto competia recolher a documentação para que no futuro outros pudessem desdobrar-se na sua análise. Isso evitaria o envolvimento do historiador com questões contemporâneas que pudessem suscitar paixões que comprometessem a neutralidade e o distanciamento necessários: "A história de uma época não pode ser escrita pelos coevos", afirmava o conselheiro Olegário. Entretanto, em inúmeras vezes, o IHGB converteu-se em tribuna política, envolvendo-se em questões contemporâneas. Nos primeiros anos da República, aumentou consideravelmente o número de eclesiásticos que utilizavam o discurso de posse no Instituto como forma de atacar a separação entre Igreja e Estado sob a roupagem de patriotismo e tradição, tão caros à agremiação: "O patriotismo ateu é uma criação nova, absurda e monstruosa. O altar e o lar são os dois pólos históricos da pátria; pro aris et focis, é o grito secular do patriotismo."18 Aproveitava-se também o momento para criticar o positivismo, pois o elemento 
unificador dos brasileiros, superior às questões políticas e atribuidor de identidade era a religião:

"Propõe-se ao povo brasileiro o positivismo para substituir a religião de Jesus Cristo. Protesto. Protesto não só como padre, mas também como brasileiro. (...) Querem-me à força homem de partido; e, pois, eu declaro: não sou republicano nem monarquista; sou católico." 19

Não existia, no entanto, uma homogeneidade absoluta dentro do Instituto. Os velhos membros, ligados à antiga ordem, iam sendo paulatinamente substituídos por outros mais jovens, educados à luz do positivismo, que impregnou a geração de 70, sobretudo a partir da Escola Militar. Ocorreu, porém, que muitos dos representantes da nova geração, ao se incorporarem ao Instituto, cederam à sua forma de organização, à idéia de consenso e ao temor de que suas idéias fossem interpretadas como políticas. E muitas vezes o Instituto emitiu seu desacordo com as interpretações históricas consideradas dissonantes.

\section{As Instituições locais e a História Nacional: O Arquivo Público Mineiro e o Instituto Histórico e Geográfico de Minas Gerais}

Apesar de manter como modelo o IHGB, as instituições locais guardavam sensível diferença em relação à matriz carioca. Em primeiro lugar, o Instituto Mineiro, fundado 18 anos após a proclamação da República, não possuía como instituição comprometimento algum com a Monarquia. Além disso, enquanto instituição local e dentro de um regime acentuadamente federalista, o IHGMG se empenharia em justificar o predomínio econômico e político de Minas Gerais na Primeira República. O mesmo ocorreu com o Arquivo Público Mineiro, órgão governamental criado anos antes, mas imbuído dos mesmos ideais. Várias pessoas eram filiadas às duas instituições; havia ainda forte contato com o IHGB e ampla circulação de idéias. Entretanto, pelas suas especificidades, ambas as instituições iriam debruçar-se com especial afinco sobre a Inconfidência Mineira, tratando-a como movimento local mas simultaneamente nacional.

Criado pela Lei no 126 de 11 de julho de 1895, e promulgado pelo Decreto $\mathrm{n}^{\circ} 860$ pelo governador do Estado de Minas Gerais, Chrispim Jacques Bias Fortes, o Arquivo Público Mineiro propunha-se a "receber e a conservar debaixo de classificação sistemática todos os documentos concernentes ao direito público, à legislação, à administração, à história e geografia, às manifestações do movimento científico, literário e artístico do estado de Minas Gerais" ${ }^{{ }^{20}}$. Produto do novo regime, ao Arquivo Público competia, através da coleta de documentação pertinente, ser o porta-voz do glorioso passado mineiro - precursor ele próprio do 
período que se iniciava - e, simultaneamente, ser o espelho do novo papel desempenhado pelo Estado dentro da Federação. A partir do Arquivo Público seria tecida a legitimação do papel de Minas Gerais dentro da Federação, através da valorização do seu passado e do caráter combativo do mineiro. Segundo Xavier da Veiga, primeiro diretor do Arquivo, Minas era o Estado "onde mais radicadas se acham as tradições" que podiam vir à tona com a descentralização política. E prosseguiu: “(...)enquanto vigorou a tirania metropolitana a atitude do povo mineiro foi uma 'Inconfidência ' permanente, protestante e conspiradora, que teve em 1789 o lampejo épico de sua mais alta indignação"²1. Nada mais lógico, portanto, que Minas recuperasse o posto proeminente que ocupava no século XVIII. Para tal, a Inconfidência Mineira seria vista como o movimento mais representativo do passado mineiro, que se pretendia republicano e nacional.

A Revista do Arquivo Público Mineiro dedicaria especial atenção, portanto, a esse capítulo da nossa história. Além da publicação de documentos referentes à Inconfidência, o Arquivo colocaria em relevo os trabalhos biográficos, principalmente sobre Cláudio Manoel da Costa. Todos os artigos, via de regra, tinham a preocupação central de discutir o episódio da morte do poeta: suicídio ou assassinato? Consultando a documentação existente, baseando-se na vaga tradição oral ("um morador antigo ouviu dizer") e utilizando artigos já publicados, os autores inclinaram-se pela segunda hipótese. Porém, ao contrário da obra de Joaquim Norberto, Cláudio Manoel da Costa não é considerado cabeça da sedição, posto destinado ao alferes Tiradentes. Nas biografias dedicadas ao poeta mesclam-se a reverência literária e a romantização de sua morte.

Foi Augusto de Lima - poeta, futuro diretor do Arquivo e um dos fundadores do Instituto Histórico e Geográfico de Minas Gerais - um dos que mais se empenharam na consolidação do culto a Tiradentes, culto esse que estava alicerçado, segundo o autor, em uma base real, verdadeira, trazida à luz pelo novo regime. Solapados os preconceitos intrínsecos ao regime anterior, "surge a imagem de Tiradentes pura e radiante", como se o objeto histórico existisse pronto para ser resgatado, brotando naturalmente da documentação. Com a "liberdade de expressão", o povo pôde manifestar o respeito pelo seu herói. Foi assim com a "romaria cívica" que partiu de Belo Horizonte em direção a Ouro Preto - agora consagrada como uma espécie de terra sagrada que pariu os primeiros republicanos -, organizada pelo clube "Floriano Peixoto" em 21 de abril de 1902. Em Ouro Preto, os romeiros - dentre os quais se incluíam alunos do Ginásio Mineiro, dada a aplicação pedagógica do exemplo cívico - foram recebidos por Lúcio José dos Santos, orador oficial do clube. Após o desfile cívico discursou Augusto de Lima. "A geração atual compreende, finalmente, que a canonização cívica de Tiradentes está terminada e que agora começa seu Culto", afirmou o orador, 
na abertura de seu discurso. Logo depois, público e autoridades dirigiram-se para a cadeia, onde foi concedida liberdade a um preso em comemoração à data. Interessante combinação de sagrado e profano: a soltura de um preso era elemento comum nas comemorações da Semana Santa, sendo posteriormente proibida. Compreende-se melhor o emprego dos termos "romaria cívica" e "canonização cívica": a jovem República não iria desprezar os símbolos religiosos na elaboração do seu panteão.

No discurso proferido por Augusto de Lima na sessão magna do clube "Floriano Peixoto" de Belo Horizonte, em 15 de novembro de 1901, a História do Brasil é vista a partir do momento presente, como se todo o passado estivesse articulado na consecução de sua finalidade última, anunciada há muito, mas só viabilizada em 1889. Assim, o 15 de novembro "traduz uma aspiração nacional, como elo de uma cadeia de datas anteriores, exprimindo a ascensão, do espírito popular para a realização dos seus destinos superiores"22. Passado e presente são compreendidos dentro da mesma historicidade, uma vez que faces da mesma moeda: "Deodoro, o herói deste dia, representa Tiradentes promovido a marechal por antigüidade de um século e merecimento de martírio." ${ }^{23}$ Passando em revista os chamados movimentos precursores, deteve-se na revolta de 1720: embora ainda inviável a organização do movimento republicano, Felipe dos Santos preparou o terreno para Tiradentes: "Estava preparado o cenário para a grandiosa epopéia da liberdade nacional; o sangue do precursor Felipe bradava por um Messias que do planalto mineiro, como Cristo no sermão da Montanha, pregasse a todo o povo brasileiro o novo testamento da República." ${ }^{24}$

Outras vezes, lançou-se mão de um modelo determinista para se explicar o caráter intrépido do mineiro. Para falar sobre as origens do Partido Republicano Mineiro, remontou-se à própria constituição da capitania:

Montanheses habituados a resolver por si as dificuldades que, a cada passo, encontravam na sua árdua faina, era natural que nada esperassem da ação do centro administrativo que agia muito de longe, para lhes fazer sentir o seu benéfico influxo.

Assim sendo, foi dali que partiram as primeiras vozes reclamando a emancipação da colônia e, antes do primeiro decênio da edificação dos primeiros povoados, começaram a relampejar neles idéias de liberdade e de autonomia; e, menos de um século depois da descoberta de Minas Gerais, já lá se agrupavam os homens mais adiantados e ilustres da época e planejavam a organização de uma República independente, desligada da metrópole portuguesa, regendo-se e governando-se pelos princípios da democracia." 25

Nos anos iniciais da República foram publicados os artigos mais inflamados que postulavam o caráter heróico de Tiradentes. Isso se deveu não só ao fato de os escritores estarem "livres" das amarras oficiais, como também - ou me- 
lhor dizendo, principalmente - pelo extravasamento do ardor republicano. Um deles foi o de Eduardo Machado de Castro, um dos signatários do manifesto de fundação do PRM, professor do Liceu Mineiro, da Escola Normal e da Escola de Farmácia de Ouro Preto. No seu texto, carregado de citações pouco exatas, aludindo inúmeras vezes à tradição oral (como a que retoma a idéia do "comboio sinistro" - que nunca existiu -, em que todos os presos teriam sido remetidos juntos ao Rio de Janeiro), Machado de Castro procurou centrar fogo no trabalho de Joaquim Norberto ${ }^{26}$. Esse texto foi utilizado por todos aqueles que buscaram recuperar (ou ao menos questionar) a memória do espetáculo junto à população. Lúcio José dos Santos também aludiu indiretamente a esse trabalho, ao colocar o seu livro sobre o papel de Tiradentes na Inconfidência como meio-termo tanto ao trabalho preconceituoso e detrator de Joaquim Norberto como ao panfleto muitas vezes sem fundamentação empírica de Machado de Castro.

Também as discussões sobre o estatuto da história - embora esse não fosse o objetivo principal do arquivo - ocuparam as páginas da revista. Um dos poucos momentos em que esse tema foi abordado foi na conferência de abertura das aulas em março de 1907, na Escola Normal Modelo em Belo Horizonte, pelo professor Aurélio Pires, lente da cadeira de Geografia, História e Educação Moral e Cívica da escola e futuro presidente do Instituto Histórico e Geográfico de Minas Gerais. Na aula o professor discutiu se o estatuto científico podia ou não ser aplicado à história como o era para outras ciências, ancorado na monografia do mineiro Pedro Lessa, publicada na Revista do IHGB. Buscava-se mais uma vez aliar o exemplo pedagógico proporcionado pela história às novas contribuições metodológicas e teóricas. Discussões desse tipo foram mais freqüentes em uma outra instituição mineira, criada mais de dez anos após o Arquivo Público.

Em 1907 foi fundado na capital mineira o Instituto Histórico e Geográfico de Minas Gerais, por iniciativa do presidente do Estado, João Pinheiro, e nomes de destaque nos meios políticos e intelectuais, como Augusto de Lima, Diogo de Vasconcelos, Carlos Otoni, Nelson de Senna, Aurélio Pires, e inspirado pelo clube "Floriano Peixoto". Como as instituições congêneres locais, o IHGMG espelhava-se na sua "matriz", o IHGB. Embora seus estatutos fossem praticamente idênticos, dos objetivos à hierarquia interna, não gozou o IHGMG do mesmo prestígio e recursos: o primeiro volume da sua revista, instrumento indispensável para a divulgação da instituição, só foi publicado em 1945, referente aos dois anos anteriores. Enquanto isso, na chamada primeira fase (até 1927), o resumo das deliberações tomadas era veiculado pelo órgão oficial do Estado, o que pode ser atribuído à importância política de seus membros. Durante o período estudado o Instituto não possuía sede própria, denotando o caráter relativamente precário em que funcionava a instituição. Em 1927, por iniciativa do presidente Antonio Carlos, celebrou-se o "renascimento" do instituto, com a promoção de 
conferências mensais e a presença de membros de outras instituições e de projeção nacional, como o caso do conde de Afonso Celso e de Olavo Bilac. No entanto, a publicação da revista teria de aguardar ainda quase duas décadas.

O IHGMG acabou estabelelecendo relações mais íntimas com o Arquivo Público Mineiro, tanto pela circulação entre seus membros como pela publicação, pelo Arquivo, dos estatutos do Instituto, algumas atas das sessões e conferências pronunciadas, muitas vezes transcritos do Minas Gerais.

Os objetivos do IHGMG eram semelhantes aos dos outros Institutos Históricos locais. Mais do que nunca, sob a República Federativa - e com relativo atraso -, buscava-se legitimar, pela via do passado, o papel desempenhado pelo Estado no presente.

O Instituto dedicou largo espaço à Inconfidência - basta lembrar que é das suas fileiras que iria sair o autor do primeiro estudo revisionista de fôlego sobre a Inconfidência Mineira, que reabilitou oficialmente Tiradentes. Celebrando o "renascimento" do Instituto em 1927, o professor Aurélio Pires proferiu uma conferência sobre Tiradentes:

É por isto, meus senhores, que o Instituto Histórico e Geográfico de Minas Gerais, um de cujos fins precípuos é investigar e coligir documentos concernentes à história de nosso Estado; é por isto que esta associação, cônscia de que a comemoração do nosso passado é a melhor preparação do futuro, vos convocou hoje, aqui, para comemorarmos uma de nossas datas máximas, para relembrarmos um acontecimento que derrama luz intensa nas páginas dos nossos fastos, para evocarmos a figura escultural, épica, apostolar, do imortal montanhês, do excelso mártir, de Tiradentes, enfim, cujo nome, tendo já transposto as galerias da história, se incorporou ao nosso patrimônio moral, ingressou no escínio opulento das caras tradições do livre povo mineiro. ${ }^{27}$

Esse trecho inicial do seu discurso é lapidar pela transparência dos seus objetivos. Não existem máscaras: não é o estatuto científico da história que está sendo evocado para destacar Tiradentes, como fará Lúcio José dos Santos, através do uso das fontes. O que importa aqui como exemplo pedagógico e cívico - trata-se de um professor falando - é a lição moral que Tiradentes pode oferecer. Por isso o vocabulário empregado na sua descrição é religioso: é esse o caráter de que se reveste o culto. Via de regra, será essa a linguagem dos livros didáticos: a Inconfidência será representada enquanto ação moral de uma personagem. É por isso que não existe problema em incorporar heróis vencidos ao panteão nacional:

Quando os revolucionários triunfam, as lições contra o despotismo são imediatas e positivas, todos as compreendem; porém quando os planos e os sonhos de liberdade fracassam, só muito tempo passado é que vamos aprender nos feitos e na 
abnegação dos seus corifeus. São os dois casos típicos de Tiradentes e Felipe dos Santos.

Foram vencidos em seus ideais de liberdade, e por eles morreram; porém hoje, quase dois séculos decorridos, servimo-nos desses mártires para, mostrando aos novos a inteireza de seus caráteres, a firmeza de suas convicções, colhermos com isso uma regeneradora lição de civismo. ${ }^{28}$

Em novembro de 1927 encontravam-se definidas e aprovadas - por iniciativa do presidente honorário do Instituto e presidente do Estado, Antônio Carlos - as conferências a serem realizadas como parte do programa de revitalização do Instituto. Os temas - referentes à história de Minas - seriam desenvolvidos em sua maioria por membros do Instituto, como Nelson de Senna (aborígine mineiro), Lúcio dos Santos (Conjuração Mineira) e convidados, como Afonso Taunay (descobertas auríferas) e Basílio de Magalhães (Capitanias de Minas e São Paulo). As conferências tiveram início no ano seguinte. Na sessão de 21 de abril, além da leitura do final da sentença condenatória de Tiradentes, teve lugar a conferência "A conjuração mineira: suas causas, seus espíritos, seus efeitos", de Lúcio José dos Santos. Já tendo apresentado trabalho no Congresso de América promovido pelo IHGB em 1922, que foi publicado em 1927, sua conferência repetiu as idéias que desenvolveu, debruçando-se sobre a figura de Tiradentes. Apesar do estudo minucioso das fontes - usadas para "provar" sua premissa de que Tiradentes foi o idealizador do movimento - também não lhe escapou a uma certa visão moralizante, principalmente quando descreveu a leitura da sentença:

Cenas lamentáveis de alegria, seguindo-se a cenas lamentáveis de pavor, na sala do Oratório, deixaram-nos provas da fraqueza dos conjurados. Um homem se conservou superior a tudo isso, como o único capaz de salvar a dignidade de seus patriotas, prestes a soçobrar em lamentável naufrágio - Tiradentes. ${ }^{29}$

Esta descrição, amparada em narrativa de um religioso, conserva a marca do local (visão de mundo) de sua produção. Quando historiadores, políticos, pintores procuram aproximar Tiradentes de Cristo, "transformando-o" em herói cristão, não estão criando uma representação nova: estão apenas bebendo em uma fonte contemporânea ao evento. E pelo fato de ser contemporânea acabou sendo vista, por muitos, como mais fidedigna.

Após discorrer longamente sobre a Inconfidência, Lúcio dos Santos, como em seu livro, concluiu que "é lícito duvidar que nos fosse preferível o advento da República em 1789, em vez de seguirmos uma evolução mais segura, através da Monarquia"30. Assim, a visão dominante durante a República Velha, também disseminada nos manuais didáticos, é que a Monarquia evitou a fragmentação 
territorial e a sucessão de ditadores, como ocorreu com as ex-colônias espanholas.

\section{NOTAS}

${ }^{1}$ Anais da Câmara, 1827, tomo II, p. 86, apud Octavio Tarquínio de Souza, História dos fundadores do Império do Brasil. Volume V - Bernardo Pereira de Vasconcelos, Rio de Janeiro: José Olympio, 1960, p. 107. Artigo publicado postumamente, com a revisão de Lilian Starobinas.

${ }^{2}$ Idem, p. 202. Segundo Otávio Tarquínio de Souza, as idéias regressistas não representam um desvio na carreira política de Vasconcelos: existiam em germe desde o início do período regencial. Idem, p.160.

${ }^{3}$ RIHGB, tomo 23, 1865, p. 332.

${ }^{4}$ Idem, tomo 51, 1888, p. 344.

${ }^{5}$ Idem, tomo 4, 1842, pp. 392-393.

${ }^{6}$ Idem, tomo 5, 1843, p. 400.

${ }^{7}$ RIHGB, suplemento ao tomo 51, 1888, p. 43. Após a proclamação da República, o senador Taunay afasta-se da vida pública.

${ }^{8}$ Parecer assinado por Severiano Fonseca, Sacramento Blake e Cesar Augusto Marques. RIHGB, tomo 55, 1892, p. 406.

${ }^{9}$ Idem, tomo 57, 1894, p. 395.

${ }^{10}$ PEIXOTO, José Maria Pinto. "Duas palavras sobre D. Pedro I na época da Independência". In RIHGB, tomo 56, 1893, p. 25.

${ }^{11}$ MATTOS, Ilmar Rolhoff de. O tempo saquarema. São Paulo/Brasília, Hucitec/INL, 1987, pp.264-265.

${ }^{12}$ RIHGB, tomo 75, 1912, p. 237.

${ }^{13}$ Apud PRIMITIVO, Moacyr. A instrução e o Império, Op. cit., $2^{\circ}$ v.

${ }^{14}$ RIHGB, tomo 1, 1939, p. 48.

${ }^{15}$ Discurso de posse do sócio Silvio Rangel de Castro, RIHGB, tomo 107, vol. 161, 1930, p. 786. A partir de 1919, a numeração da revista muda e passa a conter o volume.

${ }^{16}$ Marquês de Paranaguá, RIHGB, tomo 69, 1908.

${ }^{17}$ Discurso do Primeiro secretário Manoel de Araújo Porto-Alegre. RIHGB, tomo 21, 1858, p. 513.

${ }^{18}$ Discurso de posse do Arcebispo metropolitano da Arquidiocese de S. Sebastião, D. Joaquim Arcoverde. Idem, tomo 61, 1898, p. 651.

${ }^{19}$ Discurso de posse do Padre Júlio Maria. Idem, tomo 62, pp.372-381, 1900.

${ }^{20}$ RAPM, ano I, fasc. I, jan./março 1896, p. 175.

21 "Palavras preliminares". In RAPM, ano I, fasc. I, jan./março 1896, pp. iii e iv. José Pedro Xavier da Veiga (1846-1900) foi jornalista, político filiado ao Partido Conservador durante o Império - várias vezes deputado e senador no período 1891-1895 - e escritor, autor das Ephemerides Minei- 
ras. Fundador e diretor do Arquivo Público nos primeiros anos, era também sócio correspondente do IHGB.

22" A luta colonial pela independência". In RAPM, ano VII, fasc. III e IV, julho/dez. 1902, p. 868.

${ }^{23}$ Idem.

${ }^{24}$ Idem, p. 876.

${ }^{25}$ PIRES, Antonio Olyntho dos Santos. "A idea republicana em Minas Gerais; sua evolução; organização definitiva do Partido Republicano.” In RAPM, ano XXI, pp. 17-40, 1927.

${ }^{26}$ CASTRO, Eduardo Machado de. "A Inconfidência Mineira - narrativa popular". In RAPM, ano VI, fasc. III e IV, julho/dez. 1901.

${ }^{27}$ 'Instituto Histórico e Geográfico de Minas Gerais (Origem; histórico; fins; sede). In RAPM, op. cit., p. 130.

${ }^{28}$ DUARTE, A. Teixeira. "Sedição de Villa Rica - 1720 (Felipe dos Santos Freire)". Conferência pronunciada no IHGMG a 28 de setembro de 1913. RAPM, ano XVIII, 1913, pp. 575-587.

${ }^{29}$ Idem, p. 62. Trata-se do texto "Últimos momentos dos Inconfidentes de 1789, pelo frade que os assistiu em confissão", de frei Raimundo da Anunciação Penaforte. In Autos da devassa da Inconfidência Mineira. Brasília: Câmara dos Deputados, 1976, vol. 9.

${ }^{30}$ RAPM, ano XXII, 1928, p. 65.

Artigo recebido em 03/2000. Aprovado em 09/2000. 